Маријана Папрић ${ }^{1}$

Универзитет у Београду

Учитељски факултет
удК 811.161.1'161.1:1/3

371.671:811.161.1

DOI 10.18485/zivjez.2016.36.1.10

Оригинални научни рад

\title{
СИНТАКСИЧКЕ ОСОБЕНОСТИ НАУЧНОГ СТИЛА У УЏБЕНИЦИМА РУСКОГ ЈЕЗИКА СТРУКЕ ЗА ХУМАНИСТИЧКИ ПРОФИЛ
}

Предмет рада је опис и анализа синтаксичких особености научног стила у домаћим уџбеницима руског језика струке за хуманистички профил. Описана је специфичност функционисања научног стила, његова стандардизована структура и типске конструкције, истакнут неодређенолични, уопштенолични и безлични карактер језика науке. Стилистичка анализа научних текстова у поменутим уџбеницима показала је да се специфичност језика науке у великој мери испољава управо на синтаксичком нивоу, што има значајне импликације за методику наставе језика струке - издвајање обавезног синтаксичког минимума за различите етапе наставе, начин организације и презентације језичке грађе, као и формирање објективне лингвистичке базе за развијање навика читања, превођења и самосталног служења научно-стручном литературом.

Кључне речи: руски језик струке, уџбеник руског језика струке, научни стил, настава стилистике, језик науке

У професионално оријентисаној настави руског језика за студенте нефилологе настава стилистике заузима важно место. Подручје стилистике, са акцентом на специфичне одлике научног стила, једно је од најрелевантнијих и најактуелнијих у изучавању руског језика струке и истовремено један од циљева наставе. Овладавање научним стилом актуелно је како на студијама филологије, тако и у нефилолошком образовном профилу, а у зависности од конкретних циљева који се постављају

1 marijana.papric@uf.bg.ac.rs 
у настави може се одвијати на рецептивном (праћење научне и ужестручне литературе) или продуктивном плану (самостално састављање усмених и писаних саопштења на научне и стручне теме) (в. Кончаревић 1996: 185-186).

Настава стилистике на нефилолошким факултетима није издвојена у засебан аспекат наставе, већ се одвија комплексно, тј. паралелно са лексиком, граматиком и другим језичким делатностима - посебно читањем и превођењем ужестручних текстова. Имајући у виду чињеницу да језичке вештине читања, превођења, као и самосталног служења научно-стручном литературом на руском језику представљају важне компоненте професионалне комуникативне компетенције стручњака свих профила, неопходно је систематски упознавати студенте са основним одликама и начином функционисања језика науке, тј. обезбедити одређени минимум знања о његовим стилским, лексичко-граматичким и синтаксичким одликама.

Дакле, осим познавања терминолошке лексике и граматике, студенти нефилолози морају поседовати и одређена знања о функционалним стиловима у руском језику. Међутим, основу њихове стилистичке компетенције треба да представља познавање научног стила, његових лексичких, граматичких и морфо-синтаксичких одлика.

Руководећи се наведеним циљевима, али и потребама науке и наставне праксе, спровели смо лингвистичку анализу актуелних уџбеника руског језика струке за хуманистички профил (синтаксички ниво), издвојили најважније синтаксичке особености научне прозе и указали на њихов значај и улогу у изграђивању професионалне комуникативне компетенције, нарочито вештине самосталног читања, правилног декодирања писаних саопштења, као и служења научно-стручном литературом на руском језику.

Као предмет анализе послужили су нам актуелни уџбеници руског језика струке за студенте филозофских, учитељских, педагошких и правних факултета у Србији, као и Правословно богословског факултета Универзитета у Београду (в. Извори).

Стилистичка анализа научних текстова у поменутим уџбеницима показала је да поред лексичких и морфолошких катего- 
рија постоји знатан проценат синтаксичких појава типичних управо за научни стил. Овде, пре свега, имамо у виду неодређенолични, уопштенолични и безлични карактер научне прозе, партиципске и адвербијалне обрте, номинативне конструкције, зависно-сложене типове реченица и сл.

У уџбеницима које смо прегледали уочени су следећи типови реченица:

1) Неодређено-личне реченице са предикатом у облику трећег лица множине садашњег, ређе - будућег времена или у облику множине прошлог времена.

Помимо этого проводятся общеразвивающие занятия: музыка, физкультура, иногда хореография, искусство, имеется предмет «окружающий мир», на котором ученикам просто рассказывают обо всём, с чем они могут встретиться в жизни (ВОИ: 235).

Вас научат разбираться в возрастных психологических особенностях детей (начиная с рождения), управлять коллективом, организовывать индивидуальную и групповую работу, развивать интересы школьников (ВОИ: 238).

Этимологией называют также результат раскрытия происхождения слова (РЈФФ Н I: 31).

Да и продукция, выпускаемая заводом, хорошо знакома детям: в каждой семье ежедневно употребляют масло, молоко, часто в питании используется творог, сметана (РЈ ВОТ: 58).

Когда говорят о законах, имеют в виду либо правовые (юридические), либо моральные правила (РЈП: 15)

Произошло это из-за услуги «SMS дневник», которую нам внедрили в учебно-воспитательный процесс (РЈ ВОТ: 146).

Долгое время считали, что мир непознаваем (РЯРК: 101).

2) Уопштено-личне реченице организоване помоћу глагола у облику 1. лица множине садашњег или будућег времена: 
Выделяя специфику философского осмысления глобальных проблем, отметим наиболее важные, присущие только этой форме познания особенности, вытекающие из основных функций философии (РЯРК: 159).

Причин нежелания учиться много. Попробуем в них разобраться (PJ BOT: 44).

Подытожим рецензию. [...]

Пожелаем, чтобы уровень БТ и далее продолжал повышаться, способствуя тем самым развитию российской церковной науки и духовному образованию в целом (PJT: 89).

Итак, обобщим все сказанное и сделаем выводы (РЈФФ Н I:163).

Отметим лишь тот факт, что [...] (РЈП: 58).

На семантичком плану, ови облици су блиски императиву, што је показатељ специфичног функционисања глаголских времена у руској научној прози. Наведене реченице типичне су за исказивање резултата радње, али у њима је често индиректно садржан позив на заједничко учествовање у њој (тзв. инклузивни императив).

3) Безличне реченице са предикатом израженим у облику пасива: считается, указывается, говорится, отмечается, будет сказано и сл. (уместо неодређено-личних реченице са облицима говорят о ..., пишут $о$... које се веома ретко срећу у научном стилу):

Считается, что у девочек чувство коллективизма развито намного сильнее, чем у мальчиков (ВОИ: 51).

Справедливо отмечается, что новый учебный материал усваивается хорошо только после того, как он хорошо понят (РЯРК: 101).

Думается, что из всего богатства, созданного русским народом в дховной области, самое великое - это именно национальная литература, которая представляет собой органичную часть духа России, её суть, её природную стихию (РЯРК: 254). 
В отличие от антропометрии о дактилоскопии подробно говорится в учебниках криминалистики (РЈП: 58).

Научном стилу својствени су различити типови безличних реченица:

а) Безличне реченице са модалним речима које изражавају могућност, неопходност, немогућност (можно, надо, нельзя) и инфинитивом:

Нельзя стать культурным человеком, не овладев знанием тех культурных богатств, которые накопило человечество (РЯРК: 158).

Формальное мышление особое искусство; Овладев им, можно достигнуть больших успехов в работе (РЯРК: 158).

По словам В. А. Сухомлинского, чтобы ребёнок научился понимать природу, чувствовать её красоту, читать её язык, беречь её богатства нужно прививать ему эти чувства с детства (РЈУФ В: 277).

Надо ещё помочь детям приблизить к себе природу, впустить её в свой собственный мир, «приручить» её (РЈУФ В: 273).

б) Безличне реченице чији је главни члан изражен безличним глаголом или личним глаголом у безличној употреби са постфиксом -ся.

Не следует ребенка отдавать в детсад и до того момента, пока он не научится хоть немного говорить, так как ребенок должен иметь возможность рассказать родителям о том, что с ним произошло за день (PJ ВОT: 46).

В области международного торгового права следует различать универсальные и региональные нормы (РЈП: 109).

Разговаривать с родителями следует спокойно и доброжелательно (РJ ВОТ: 145).

Bсе, что поется и читается в храме в этот день, - очень важное напоминание всем нам о греховном повреждении человеческой при- 
роды, о том, что человек в его сегодняшнем состоянии - не такой, каким задумал и создал его Творец (РЈ КМЦ: 48).

в) Безличне реченице са предикативним прилозима на -о:

Раз дефективные дети живут среди нас, необходимо приложить все усилия, чтобы они стали полноправными членами общества (ВОИ: 242).

Из всего вышеизложенного нетрудно понять причины нелюбви к школе (РЈ ВОТ: 45).

Любопытно заметить, что в науке не существует общепризнанной хронологии истории апостольского века (PJT: 21).

Сви наведени типови реченица могли би се сврстати у групу уопштених исказа којима се само констатују одређене чињенице, без указивања на конкретног вршиоца радње. Радња изражена предикатом најчешће није смештена у конкретан временски и просторни контекст, тј. предикатом није изражена радња као таква, већ пре радња као обележје, тј. трајна особина. На основу тога може се закључити да су руској научној прози на првом месту својствени уопштени искази са значењем трајног обележја, а тек на другом месту уопштени искази за изражавање радње (Митрофанова 1985: 82-87).

За исказивање радњи и процеса у руском научном стилу у широкој употреби су глаголске и партиципске пасивне конструкције у којој је субјекат изражен инструменталом или је изостављен:

Ранними апологетами христианства ветхозаветные запреты на любое изображение Божие воспринимались столь же буквально, как и евреями (РЈT: 21).

Именно поэтому так важен в экологическом воспитании начальный этап школьного обучения, когда стихийные знания о культуре взаимоотношения с природной средой систематизируются и обобщаются (РЈУФ В: 276). 
В то же время установлено, что неумеренное использование компьютерных игр (как впрочем и других игровых способов проведения досуга) может приводить к психопатологическим симптомам (PJ BOT: 57).

К 1971 году была создана сеть с 23 пользователями в разных концах США.

В 1972 году впервые ARPANET была продемонстрирована перед публикой (PJ ВОТ: 63).

Пасивне конструкције примењују се и у другим језичким стиловима, али у знатно мањој мери, што је разумљиво, ако се има у виду садржај научне прозе која одражава објективне резултате и износи конкретне чињенице из стварности која нас окружује. Научно мишљење базира се на појмовима који су изражени апстрактно, логично и уопштено, што захтева специфична лексичко-граматичка и синтаксичка средства.

Анализом синтаксе просте и сложене реченице лингводидактичари су дошли до још једног значајног закључка који говори о специфичности и непоновљивости научног израза. У њему на синтаксичком плану делује тзв. синтаксичка компресија, тј. кондензација (под „синтаксичком кондензацијом“ подразумева се примена номинативних елемената или обрта у реченици, које у другим језичким стиловима замењује зависна реченица). Као резултат, на месту очекиване зависне реченице имамо партиципске и прилошке обрте или предлошко-падешке конструкције. На пример: при повышении температуры - уместо когда (если) температура повышается; с увеличением объема - уместо по мере того как объем увеличивается и сл. Изостављањем глагола повећава се информативна вредност именске речи, долази до кондензовања, тј. компресије или скраћивања исказа, што је једна од значајних одлика научне прозе (в. Оспанова 2013; Митрофанова 1985: 88-94; Јујси 2014).

Наша анализа потврдила је да су за језик хуманистичких наука карактеристични: 
Маријана Папрић

\section{1) Партиципски обрти:}

Все разнообразные методы, используемые в педагогических исследованиях, можно подразделить на общенаучные и специальные (РЯРК: 168).

Общенаучные методы познания - это методы, носящие общенаучный характер и применяемые во всех или в ряде областей [...]. Общенаучные методы тесно связаны с группой конкретно-научных методов, применяемых в определённой области и не выходящих за её пределы (РЯРК: 168).

Наибольшую известность принесла Выготскому созданная им психологическая теория, приобретшая широкую известность под названием «Культурно-историческая концепция развития высших психических функций», теоретический и эмпирический потенциал которой не исчерпан до сих пор (ВОИ: 241).

Одаренным детям, обладающим творческими способностями и живым умом, просто необходимы доверие со стороны родителей и возможность время от времени выходить по собственному желанию за рамки общепринятого поведения (РЈ ВОТ: 48).

Этимология [...], отрасль языкознания, исследующая происхождение слов, их первоначальную структуру и семантические связи (РЈФФ Н I: 31).

2) Конструкција са глаголским прилогом:

Проникая в глубины космоса, учёные разрабатывают различные модели Вселенной (РЯРК: 158).

Вступая в связи друг с другом, объекты могут создавать единый целостный объект (РЈФФ Н I: 160).

В ходе «пальчиковых игр» дети, повторяя движения взрослых, активизируют моторику рук (ВОИ: 228).

Находясь в преддверии поста, мы пересматриваем все то, чем живем: что является для нас главным, а что - второстепенным (РЈ КМЦ: 48) 
Применив новый метод исследования, можно добиться хороших результатов (РЯРК: 106).

3) Предлошко-падешке конструкције:

В результате исследований различных проблем экологического воспитания, проведённых в 80-90-ые годы, были определены методологические и теоретические основы экологического воспитания в соответствии с возможностями конкретного возраста [...] (РЈУФ В: 276).

Исследования показывают, что для становления учителя и формирования его творческого почерка решающее значение имеют первые годы работы (РЈУФ В: 294).

В самом Священном Писании слово «церковь» употребляется и для указания на ее неземную природу (РЈ КМЦ: 35).

При анализе цвета в рисунках нужно обращать внимание на те цвета, присутствие которых в рисунке преувеличенно или неоправдано (ВОИ: 233).

B силу неспособности Центра быстро и эффективно регулировать свои отношения с регионом, между ними происходит постоянное увеличение нерешённых конфликтов (РЯРК: 120).

Именно благодаря этому она (философия) и оказывала на протяжении тысячелетий заметное влияние на все сферы человеческой деятельности, в кокторых так или иначе применялись методы теоретического мышления (РЯРК: 172).

Однако по мере применения тестов и накопления полученных данных росли и сомнения в том, что именно эти результаты отражают (РЯРК: 148).

Наведени партиципски и адвербијални обрти, као и предлошко-падешке конструкције, како истичу лингвисти, врше у научном тексту функцију кондензације: „Конденсационные свойства средств осложнения обусловлены тем, что органи- 
Маријана Папрић

зующие их лексемы - причастия, деепричастия, отглагольные существительные - это слова с двойственными, гибридными характеристиками, что, естественно, увеличивает семантическую емкость и морфолого-синтаксические потенции этих лексем, позволяет избавиться от избыточных многословий хотя бы за счет конструктивных усложнений, вместить в пределы одной фразы максимум необходимой информации“ (Митрофанова 1985: 91-92).

Дакле, синтаксу научног стила карактерише стандардизованост структуре, типске конструкције, најчешће повезане различитим везничким средствима у сложену синтаксичку целину, што нам омогућава да разликујемо једну стилску варијанту од друге, тј. да окарактеришемо дати функционални стил, у односу на друге стилове. Управо специфична синтаксичка обележја представљају основну карактеристику научне прозе, јер ако је основна јединица говора - реченица, онда се својеобразност одређеног функционалног стила испољава управо на синтаксичком нивоу (в. Васиљева 1976: 131-151; Митрофанова 1985: 72-96; Тројанска 1989; Буре и др. 2003: 56-66; Кончаревић 2011: 20-21; Гољак 2012: 132-133).

За језик науке карактеристичне су и тзв. парентезе које врше функцију конектора, односно повезују једну мисаону целину са другом, наглашавајући на тај начин логичко-композициони ток излагања, редослед навођења чињеница или извор информације: итак, таким образом, с одной стороны, с другой стороны, следовательно, наконец, во-первых, во-вторых; конечно, бесспорно, несомненно, по-видимому; согласно концепции, по мнению автора и сл. На пример:

Во-первых, труд как главное условие возникновения и существования сознания имеет коллективный характер (РЈФФ Н I: 163).

Учитель - это специалист «два в одном». Во-первых, он должен отлично знать предмет или несколько предметов, которые собирается преподавать. Во-вторых, уметь эту информацию донести до учеников (РJ ВОT: 139). 
Таким образом, философия серебряного века неразрывно связана со всей предшествующей философской мыслю России, она - её закономерное продолжение и развитие (РЯРК: 278).

Конечно, с точки зрения безопасности внедрение подобных технологий можно назвать действительно позитивным явлением (PJ BOT: 149).

Итак, с одной стороны, гениальный учёный с мировым именем, с другой - выдающийся художник и поэт. Трудно поверить, что эти таланты совмещались в одном лице (РЯРК: 117).

Согласно концепции Максима Исповедника, «благость» творения обретается в самом творении, а не только в единении его с Божественной Сущностью (И. Мейендорф) (РЈT: 21).

Следовательно, эмоциональная адаптация - довольно скоротечный процесс, причем процесс пассивный, не зависящий или мало зависящий от сознания (РЈУФ В: 295).

Следовательно, небытие - относительно, бытие - абсолютно (РЈФФ Н I: 161).

Наведена разматрања показатељ су морфо-синтаксичке и структурно-семантичке особености језика науке, његових специфичних обележја која га чине јединственим у односу на друге функционалне стилове. Дата разматрања наводе на низ методичких закључака:

1. Специфичност функционисања језика науке, употреба стручне терминологије, граматике и карактеристичних синтаксичких модела, морају бити предмет посебног изучавања у оквиру наставе руског језика струке.

2. Синтакса научног језика са својом стандардизованом структуром и специјалним речником представља релативно мали део синтаксе општег језика, што је добра предиспозиција за минимизацију, тј. издвајања обавезног синтаксичког минимума за различите етапе наставе језика струке.

3. Наведене специфичности научног стила намећу потребу за одређеним редоследом увођења синтаксичког материјала, 
уз поштовање принципа дозирања, градираности материјала по тежини, и одабир синтаксичких модела и образаца који на најадекватнији начин презентују функционисање језика у научној сфери.

4. Резултати лингвистичких истраживања у оквиру научног стила поуздан су оријентир предавачима, методичарима и ауторима уџбеника у тражењу најрационалнијег и најцелисходнијег начина организације и презентације наставних садржаја, тј. представљају објективну лингвистичку базу за одабир ограниченог, али довољног наставног материјала за извођење наставе руског језика у професионалне сврхе.

5. У току саме наставе студентима треба непрекидно усмеравати пажњу на специфична значења и употребу лексичких јединица, граматичких модела и синтаксичких структура научног стила у односу на друге стилско-функционалне варијанте руског језика, како у процесу писане и усмене продукције не би дошло до нарушавања језичке и стилистичке норме општег језика, као и унутарјезичких и унутарстилистичких норми језика науке.

\section{ИЗВОРИ}

PJ ВОТ - Белокапић 2009: Белокапић Шкунца, В. (2009). Руски језик: васпитно-образовна тематика. Београд: Универзитет „Браћа Карић“.

РЈУФ В - Богдановић 1998: Богдановић, С. (1998). Руски језик за студенте Учитељског факултета. Врање: Учитељски факултет.

РЈФФ Н I - Величковић 1993: Величковић, Д. (1993). Руски језик I за студенте Филозофског факултета. Ниш: Филозофски факултет.

РЯРК - Дамљановић 2009: Дамљановић, Д. (2009). Русский язык, русская культура: для студентов гуманитарного профиля. Београд: Завод за уџбенике.

PJT - Кончаревић 2011: Кончаревић, К. (2011). Руски језик у теологији: обликовање теолошког текста, техника превођења. Београд: Православни богословски факултет: Институт за теолошка истраживања. 
РЈ КМЦ - Кончаревић 2014: Кончаревић, К. (2014). Руски језику комуникацији и мисији Цркве: функционални стилови, ресурси, жанрови. Београд: Православни богословски факултет: Институт за теолошка истраживања.

РЈП - Милинковић 2000: Милинковић, љ. (2000). Руски језик за правнике. Београд: Савремена администрација.

ВОИ - Папрић, Белокапић 2015: Папрић, М., Белокапић Шкунца, В. (2015). Воспитываем, обучаем, играем: учбеник руског језика за студенте Учитељског факултета. Београд: Учитељски факултет.

\section{ЛИТЕРАТУРА}

Буре и др. 2003: Буре, Н. А., Быстрых, М. В., Вишнякова, С. А. и др. (2003). Основы научной речи: Учеб. пособие для студ. нефилол. высш. учеб. заведений. Санкт-Петербург: Филологический факультет СПбГУ; Москва: Издательский центр «Академия».

Васиљева 1976: Васильева, А. Н. (1976). Курс лекций по стилистике русского языка: научный стиль речи. Москва: Русский язык.

Гољак 2012: Голяк, С. В. (2012). Особенности научного стиля русского языка в сопоставлении с сербским, Русский язык как инославянский, IV, 127-135.

Кончаревић 1996: Кончаревић, К. (1996). Настава страног језика на филолошким студијама: теорија и пракса. Београд: Филолошки факултет.

Митрофанова 1985: Митрофанова, О. Д. (1985). Научный стиль речи: проблемы обучения. Веб: http://www.twirpx.com/file/1550842/ (15.08.2016)

Оспанова 2013: Оспанова, Б. Р. (2013). Научный стиль речи как аспект обучения языку специальности: учебное пособие. Веб: http:// www.rae.ru/monographs/220 (15.09.2016)

Тројанска 1989: Троянская, Е. С. (1989). Обучение чтению научной литературы. В помощь преподавателю иностранных языков. Москва: Наука.

Јујси 2014: Юйсы, С. (2014). Предложно-падежные сочетания типа «предлог + отглагольное существительное» как средство синтаксической конденсации в научном стиле русского языка, Историческая и социально-образовательная мысль, 4 (26). Веб: http://www.hist-edu.ru/hist/article/view/407 (20.10.2016) 


\title{
Марианна Паприч
}

\section{СИНТАКСИЧЕСКИЕ ОСОБЕННОСТИ НАУЧНОГО СТИЛЯ В УЧЕБНИКАХ РУССКОГО ЯЗЫКА КАК ЯЗЫКА СПЕЦИАЛЬНОСТИ ДЛЯ СТУДЕНТОВ ГУМАНИТАРНОГО ПРОФИЛЯ}

\author{
Резюме
}

Предметом предлагаемой работы является описание и анализ синтаксических особенностей научного стиля в профессионально-ориентированных учебниках русского языка для студентов гуманитарных факультетов в сербской языковой среде. Цель работы подчеркнуть значимость лингвистических исследований в области языка специальности и их непосредственное влияние на создание и совершенствование процесса обучения. В работе описываются особенности функционирования научного стиля, его стандартизированная структура и типичные синтаксические конструкции, а также подчеркивается неопределенно-личный, обобщенно-личный и безличный характер языка науки. Стилистический анализ научных текстов в данных учебниках показал, что своеобразие языка науки в значительной степени проявляется именно в синтаксическом плане, что прямо отражается на методике преподавания русского языка, как языка специальности - на отборе обязательного синтаксического минимума для различных этапов обучения, способе организации и презентации языкового материала, а также формировании объективной лингвистической базы для отбора учебных материалов, развития навыков чтения, перевода и самостоятельного использования научно-специализированной литературы.

Ключевые слова: русский язык как язык специальности, учебник русского языка для студентов гуманитарного профиля, научный стиль, обучение функциональным стилям речи, язык науки

Примљено 10. септембра 2016. године Прихваћено за објављивање 18. новембра 2016. године 